\title{
Er det overhovedet demokratisk at stemme?
}

AF CHRISTOFFER BASSE ERIKSEN OG NICOLAI VON EGGERS

SLAGMARK \#72

SIDER: I 45-I 46

I dagene op til folketingsvalget den 18. juni i år inviterede Slagmark fem debattører til at diskutere forholdet mellem stemmeafgivning og demokrati. Anledningen var Søren Maus nyligt udkomne bog med den mundrette titel Hoev stemmen! - I hvilken det vises, at folketingsvalget er et ideologisk ritual, der opretholder et udemokratisk politisk system, og at det første skridt på vejen mod et demokratisk samfund er at lade vore med at stemme, hvor Mau, som undertitlen fint opsummerer, argumenterede for, at vi helt skulle lade være med at stemme til folketingsvalget. Udover at være et provokerende udsagn, som satte gang i den offentlige debat, stillede Maus bog også en række mere fundamentale spørgsmål: Hvad er et demokratisk samfund? Er det overhovedet demokratisk at stemme? Og hvis ikke, hvad er så en demokratisk handling? Det var disse spørgsmål, vi så en god anledning til at genrejse, og derfor kontaktede vi en række debattører og bad dem forholde sig til Maus tese.

Når vi nu trykker debatten, som i første omgang tog form af et online-symposium, er det, fordi diskussionerne rækker langt udover det konkrete folketingsvalg og den umiddelbare kontekst, hvori debatten fandt sted. Debattørerne forholder sig til spørgsmålet, om det overhovedet er demokratisk at stemme, på et sociologisk, filosofisk og idéhistorisk niveau, der rækker udover den umiddelbare polemik, der fulgte Maus bog op til folketingsvalget. De følgende indlæg er således ikke de sidste indlæg i en lukket debat, men de første indlæg i en på alle måder åben debat - om hvad demokrati er og hvad der skal til for at holde det i live - der lige er begyndt. 
I det følgende bringer Slagmark Debat de fem debatindlæg, der fra hvert deres perspektiv diskuterer spørgsmålet om demokrati og hvad det vil sige at stemme. De fire første artikler er kritikker af forskellige dele af Søren Maus argument for ikke at stemme. Nicolai von Eggers argumenter i sit indlæg for, at den herskende ideologi nok kræver af os, at vi skal stemme, men at dette ikke betyder, at vi kan bryde med denne ideologi ved ikke at stemme. Bue Rübner Hansen skriver med udgangspunkt i de spanske protestbevægelsers konkrete erfaringer om begrænsningen af ideologikritik. Lotte Folke Kaarsholm argumenterer med henvisning til Afghanistan for, at vi skal se demokratiet som en kraft, der ikke kan afsluttes eller lukkes ned med den parlamentariske form. Rune Møller Stahl argumenterer for, at repræsentation ikke er en hindring men et element i kampen for et mere demokratisk samfund. I debattens sidste indlæg giver Søren Mau sine kritikere svar på tiltale og argumenter for, at demokratiet er et levende princip i vores direkte omgivelser, og at kun et opgør med den herskende og abstrakte forståelse af demokrati kan bane vejen for rigtigt demokrati. 